\title{
Prevalence and genetic diversity of HCV among HIV-1 infected individuals living in Ahvaz, Iran
}

\author{
Ali Teimoori ${ }^{1,2}$, Saeedeh Ebrahimi ${ }^{1}$, Narges Keshtkar ${ }^{3}$, Soheila Khaghani ${ }^{1}$, Shokrollah Salmanzadeh ${ }^{1}$ and \\ Shokouh Ghafari ${ }^{1,4^{*}}$ (D)
}

\begin{abstract}
Background: To explore the prevalence, transmission routes and genotypes distribution of HCV in HIV-1/HCV co-infected individuals in Ahvaz, Iran.

Methods: The present cross-sectional study was conducted among HIV adult voluntary counseling and testing (VCT) clients, from September to November 2016. Reverse transcription (RT) nested PCR was performed to amplify the HCV core and 5'UTR regions from 90 HIV/HCV co-infected individuals. The PCR products were then sequenced for HCV subtyping. Genetic analysis was done by MEGA6 software.

Results: The prevalence of HCV in HIV-1-infected individuals was 58.7\%. Injection drug use (IDU) was the most common route $(99.1 \%)$ of transmission, and most of the patients $(97.8 \%)$ had a history of imprisonment. The HCV subtypes were identified as 1a (55.2\%), 3a (35.8\%), $3 \mathrm{~h}(4.5 \%), 1 \mathrm{~b}(3 \%)$ and $4 \mathrm{a}(1.5 \%)$ respectively, HCV 1a and 3a subtypes were predominant.
\end{abstract}

Conclusions: The diversity of HCV subtypes in HIV-1/HCV co-infected individuals in Ahvaz city was high, although two subtypes (1a and $3 a$ ) are predominant.

Keywords: HIV-1/HCV co-infection; HCV subtyping; prevalence of HCV, HIV, HCV, Co-infection, Genotypes

\section{Background}

Hepatitis $\mathrm{C}$ virus (HCV) and Human Immunodeficiency virus (HIV) infections are major global public health problems [1]. Because of overlapping modes of transmission, $\mathrm{HCV}$ co-infection is common in HIV infected individuals but significantly varies depending on the mode of transmission from $10 \%$ among people with high risk sexual behavior to $90 \%$ among intravenous drug users [2].

Worldwide, an estimated 71 million people have chronic hepatitis $\mathrm{C}$ virus $(\mathrm{HCV})$ infection and approximately 399,000 people die each year from hepatitis C-related liver diseases [3]. Likewise, about 2.3 million people of the estimated 36.9 million living with HIV globally have serological evidence of past or present $\mathrm{HCV}$ infection.

\footnotetext{
* Correspondence: Shokouh_gh@ymail.com

${ }^{1}$ Infectious and Tropical Disease Research Center, Health Research Institute,

Ahvaz Jundishapur University of Medical Sciences, Ahvaz, Iran

${ }^{4}$ Infectious Diseases Research Center, Birjand University of Medical Sciences,

Birjand, Iran

Full list of author information is available at the end of the article
}

$\mathrm{HCV}$-associated liver disease represents a major cause of morbidity and mortality among HIV-infected patients [4].

$\mathrm{HCV}$ is a positive-stranded RNA virus belonging to the genus hepacivirus in the family of Flaviviridae [5]. $\mathrm{HCV}$ is classified into seven major genotypes; 67 confirmed and 20 provisional subtypes. HCV genotypes differ from each other at $30-35 \%$ of nucleotide sites, while at the subtypes level exhibits nucleotide divergence typically by $<15 \%[6]$.

Recently, an eighth $\mathrm{HCV}$ genotype has been identified in four patients from Punjab, India [7].

It has already been established that the majority of $\mathrm{HCV}$ infections worldwide are caused by a few subtypes, specifically 1a, 1b, 2a, and 3a. These so-called "epidemic subtypes" were spread rapidly prior to the discovery of HCV by several routes. Many other HCV subtypes show an endemic pattern of transmission and are relatively rare that have circulated for long periods of time in a geographically restricted area [8]. 
$\mathrm{HCV}$ genotypes strongly influence the response to treatment. Therefore, understanding $\mathrm{HCV}$ genotypes is critical for appropriate treatment regimen. With conventional interferon alpha therapy, genotypes 1 and 4 are less responsive than genotypes 2 and 3. However, with new direct-acting antiviral (DAA) regimens, genotype 3 is most challenging to treat [9].

In Iran, $\mathrm{HCV}$ prevalence in the general population is estimated $0.3 \%$ [10] that is significantly lower than neighboring countries such as Afghanistan (1.1\%), Pakistan (4.7\%), Turkey (1.0-2.1\%), Kuwait (0.8\%) and Iraq (7.1\%) [11]. According to the three conducted meta-analysis, the most frequent subtypes of $\mathrm{HCV}$ in Iran were $1 \mathrm{a}, 3 \mathrm{a}$, and $1 \mathrm{~b}$ respectively. This frequency differs in cities and provinces of Iran and neighboring countries [12-14]. In Iran, most of the studies have examined chronic HCV infection among hemodialysis and multiply transfused patients, especially those with hemophilia and thalassemia. In addition, a few studies recruited patients with a prison history, tattooing, unprotected high risk sexual behavior, and intravenous drug use. However, most studies did not report the genotypes and subtypes separately, based on population groups [13]. The present study was carried out in the Ahvaz, capital city of Khuzestan province in the southwest of the Iran, bordering Iraq and Arabian countries along the Persian Gulf. The Most important finding about HCV infection in Khuzestan has been acquired from seroprevalence studies that have been conducted in thalassemic and hemodialysis patients. The results from our previous study showed that CRF35_AD was only HIV-1 circulating subtype in this area [15]. There are no data available for the $\mathrm{HCV}$ prevalence and circulating subtypes in HIV infected persons. The aim of this study was to evaluate the prevalence and genetic diversity of $\mathrm{HCV}$ in $\mathrm{HIV} / \mathrm{HCV}$ co-infected patients living in Ahvaz city, southwest of Iran.

\section{Methods}

\section{Study design and population}

This cross-sectional study was carried out in HIV/AIDS Voluntary Counselling and Testing (VCT) center in
Ahvaz city, Iran. A registry of 1237 patients with HIV-1 infection was launched until September 2016 in this center. All records were retrieved and only 390 patients were referred to the center.

The sample inclusion criteria were adult patients, who had at least one appointment in the previous 12 months, co-infected by HCV. Finally, 229 HIV/HCV co-infected patients were followed up. The exclusion criterion was current or previous therapy with DAA.

All HIV/HCV co-infected patients invited to participate in this study from September to November 2016 (3 month). A majority of co-infected persons claimed to be under DAA treatment or refused to participate in the survey. Finally, only 90 eligible patients were enrolled. The written informed consent was obtained prior to data collection in accordance with the Helsinki Declaration and patients were asked to fill the social demographic questionnaire. About $5 \mathrm{~mL}$ of peripheral blood was taken from each patient and collected in K2-EDTA vacutainer tubes. The plasma was separated by centrifugation at $400 \mathrm{~g}$ for $10 \mathrm{~min}$ and stored at $-80^{\circ} \mathrm{C}$.

\section{RNA extraction and genotyping}

Viral RNA was extracted from $140 \mu \mathrm{L}$ of plasma by using the QIAamp viral RNA mini kit (Qiagen, Germany), according to the manufacturer's instructions. The yield and purity of the RNA was determined using NanoDrop (Thermo Scientific, USA) and the samples were stored at $-80 \mathrm{C}$ for further use. To determine the genotype of $\mathrm{HCV}$, the partial region of core gene were amplified using nested polymerase chain reaction (PCR) with two sets of modified primers, as described by ohno, et al. [16] (Table 1). cDNA synthesis and the first round of PCR were performed using QIAGEN one-step RT-PCR Kit (Qiagen, Germany). I-Taq Maxime PCR Premix (iNtRON Biotechnology, Korea) was used for further amplification by nested PCR. All PCR products were purified using the QIAquick Gel Extraction kit (Qiagen, Germany) and were sequenced in both directions using a Big Dye Terminator v3.1 Cycle Sequencing kit (Applied Biosystems, USA) and the ABI PRISM

Table 1 The sequences of used primers

\begin{tabular}{|c|c|c|c|c|}
\hline Name & Sequence & Nucleotides & Orientation & Usage \\
\hline Sc2 & GGGAGGTCTCGTAGACCGTGCACCATG & $318 \rightarrow 344$ & Core/outer & Forward \\
\hline Ac2 & GAGCGGGATATACCCCATGAG(A/G)TCGGC & $758 \rightarrow 732$ & Core/outer & Reverse \\
\hline S7 & AGACCGTGCACCATGAGCAC & $330 \rightarrow 349$ & Core/inner & Forward \\
\hline 584 & CCCATGAGGTCGGC(A/G)AAGC & $749 \rightarrow 730$ & Core/inner & Reverse \\
\hline BKP-7 & CACTCCCCTGTGAGGAACTACTGTC & $38 \rightarrow 62$ & 5'UTR/outer & Forward \\
\hline BKP-8 & ATGGTGCACGGTCTACGAGACCTCC & $343 \rightarrow 319$ & 5'UTR/outer & Reverse \\
\hline BKP-9 & TTCACGCAGAAAGCGTCTAGCCATG & $63 \rightarrow 87$ & 5'UTR/inner & Forward \\
\hline BKP-10 & GCGCACTCGCAAGCACCCTATCAGG & $314 \rightarrow 292$ & 5'UTR/inner & Reverse \\
\hline
\end{tabular}


3730xl DNA Analyzer. In cases of failure of core region amplifying, 5'UTR (5'untranslated) region was amplified by using nested PCR with two sets of previously described primers [17] (Table 1).

All sequence fragments in core and 5'UTR regions were assembled using DNA Sequence Assembler v4 (2013). The assembled sequences were aligned with $\mathrm{HCV}$ reference sequences using the CLUSTALW Multiple alignments and manual editing in BioEdit software 7.2.5. The HCV reference sequences retrieved from LOS ALAMOS HCV database (http://www.hiv.lanl.gov).

Moreover, All nucleotide sequences were screened using the BLAST search tool (http://blast.ncbi.nlm.nih. gov/Blast.cgi) to search for sequence similarities to previously reported sequences in the database. The alignments were used to construct the phylogenetic tree by a neighbor-joining (NJ) method in MEGA6 software [18] using the Kimura 2-parameter (K2P) model of evolutionary [19] distance with pairwise-deletion and 1000 bootstrap replicates .

\section{Virological and immunological tests}

The HCV antibody was determined using the third-generation enzyme immunoassays (DIA.PRO Diagnostic, Bioprobes Srl, Milan, Italy). HIV-1 infection was diagnosed by using rapid HIV test followed by both ELISA and Western blot confirmatory tests, in accordance with the HIV national algorithms in Iran. CD4 cell counts were determined using the Becton Dickinson (BD) FASCount system (Becton, Dickinson, USA).

\section{Results}

In this study we analyzed all records obtained from VCT center in Ahvaz city and found that the prevalence of $\mathrm{HCV}$ in HIV-1-infected individuals was $58.7 \%$. Injection drug use (IDU) was the most common route (99.1\%) of transmission, and most of the patients $(97.8 \%)$ had a history of imprisonment. A total of $90 \mathrm{HCV} / \mathrm{HIV}-1$ co-infected patients, including $88(97.8 \%)$ men and 2 (2.2\%) women were consecutively enrolled during sampling time (3 month) from VCT center in Ahvaz, Khuzestan.

The median age of participants was 31 years (range: 18-43 years) and the median CD4+ T-cell count was 302 cells $/ \mu$ l (range: 22 to 832 cells $/ \mu \mathrm{l}$ ). Most patients were single (53.4\%) and unemployed (60\%). Educational level varied from illiterate to diploma. HCV/HIV transmission risks were injection drug use (98.9\%), heterosexual contact (74.5\%), male-to-male (MSM) sexual contact (21.1\%) and tattooing (80\%). The overall prevalence of high-risk sexual behaviors in all participants was $95.6 \%$. The majority of cases $(87.8 \%)$ were under HAART treatment. The median alanine aminotransferase (ALT) and aspartate aminotransferase (AST) were $68 \mathrm{U} / \mathrm{L}$ and 56
U/L respectively. Demographic and laboratory characteristics of participants are shown in Table 2.

Among $90 \mathrm{HIV}-\mathrm{HCV}$ co-infected patients, according to the anti-HCV test, the infection was confirmed based on a positive HCV core RNA for 64 (71.2\%) participants. Also, 5'UTR RNA was detected in 3 samples of 26 samples that failed to amplify. In total, the presence of HCV-RNA was confirmed in 67 (74.5\%) samples.

None of the included patients had previously been treated for HCV. Phylogenetic analysis of the core

Table 2 Demographic, and laboratory characteristics of HIV-HCV coinfection status groups (Total population and enrolled participants)

\begin{tabular}{|c|c|c|}
\hline Characteristic & $\begin{array}{l}\text { Total population } \\
(n=229)\end{array}$ & $\begin{array}{l}\text { Participants } \\
(n=90)\end{array}$ \\
\hline Median age, years & 32 & 31 \\
\hline \multicolumn{3}{|l|}{ Gender } \\
\hline Male & $225(98.2)$ & $88(97.8)$ \\
\hline Female & $4(1.8)$ & $2(2.2)$ \\
\hline \multicolumn{3}{|l|}{ Marital status } \\
\hline Single & $87(38)$ & $48(53.4)$ \\
\hline Married & $72(31.5)$ & $30(33.4)$ \\
\hline Divorced/separated & $69(30.1)$ & $11(12)$ \\
\hline Widow & $1(0.4)$ & $1(1.2)$ \\
\hline \multicolumn{3}{|l|}{ Occupation } \\
\hline Unemployed & $147(64.2)$ & $54(60)$ \\
\hline Self-employed & $82(35.8)$ & $36(40)$ \\
\hline Employed & $0(0)$ & $0(0)$ \\
\hline \multicolumn{3}{|l|}{ Literacy } \\
\hline Illiterate & $11(4.8)$ & $2(2.2)$ \\
\hline Primary school & $134(58.5)$ & $59(65.6)$ \\
\hline Secondary school & $82(35.8)$ & $27(30)$ \\
\hline Diploma & $2(0.9)$ & $2(2.2)$ \\
\hline University degree & $0(0)$ & $0(0)$ \\
\hline \multicolumn{3}{|l|}{ Risk factors } \\
\hline $\mathrm{IDU}^{*}$ & $227(99.1)$ & 89 (98.9) \\
\hline High risk sexual behavior & $222(96.9)$ & 86 (95.6) \\
\hline Heterosexual & $185(80.8)$ & $67(74.5)$ \\
\hline Male-to-male sexual contact & $37(16.2)$ & $19(21.1)$ \\
\hline Tattoo & $196(85.6)$ & $72(80)$ \\
\hline Prison record & $224(97.8)$ & $88(98)$ \\
\hline CD4 cell count-median cells/ $\mu \mathrm{l}$ & 244 & 302 \\
\hline HAART** & $206(90)$ & 79 (87.8) \\
\hline \multicolumn{3}{|l|}{ Liver Blood Enzymes(units/l) } \\
\hline $\operatorname{ALT}(S G P T)^{* * *}$ & 79 & 68 \\
\hline AST $(\mathrm{SGOT})^{* * * *}$ & 63 & 56 \\
\hline
\end{tabular}

* Injection drug use ${ }^{* * * *}$ Aspartate aminotransferase

** Highly active antiretroviral therapy

*** Alanine aminotransferase 
Table 3 Frequency of HCV subtypes among patients

\begin{tabular}{ll}
\hline HCV subtype & Frequency (\%) \\
\hline $1 \mathrm{a}$ & $37(55.2)$ \\
$1 \mathrm{~b}$ & $2(3)$ \\
$3 \mathrm{a}$ & $24(35.8)$ \\
$3 \mathrm{~h}$ & $3(4.5)$ \\
$4 \mathrm{a}$ & $1(1.5)$ \\
Total & $67(100)$ \\
\hline
\end{tabular}

region sequences of 64 samples showed that 35 samples were infected with genotype 1a, 23 with $3 \mathrm{a}$, three with 3 $\mathrm{h}$, two with $1 \mathrm{~b}$ and one with $4 \mathrm{a}$ (Table 3 ). As mentioned above, from cases of failure, 5'UTR RNA was amplified and detected in 3 cases. Two of them was genotype1a and the remaining was $3 \mathrm{a}$. Totally, the $1 \mathrm{a} \mathrm{HCV}$ genotype was predominant $(55.2 \%)$, followed by the 3a genotype
(35.8\%). Subtypes 4 and 5'UTR were not shown here. (Figs. 1 and 2).

\section{Discussion}

In this study, we found that the seroprevalence rate of HCV in HIV-infected people was 58.7\% (229/390). In addition, the majority of participants were male (97.8\%); due to the fact that the majority of HIV cases in Iran were male. In Iran, the prevalence of hepatitis $C$ virus varies widely among different population groups. It is estimated from $0.3 \%$ in the general populations until $32.1 \%$ among high risk populations [10]. The findings of this study revealed that the prevalence of HCV infection among HIV infected individuals was significantly higher than the general population. This occurred because the majority of co-infected individuals were injection drug users (IDUs). Our results were consistent with the

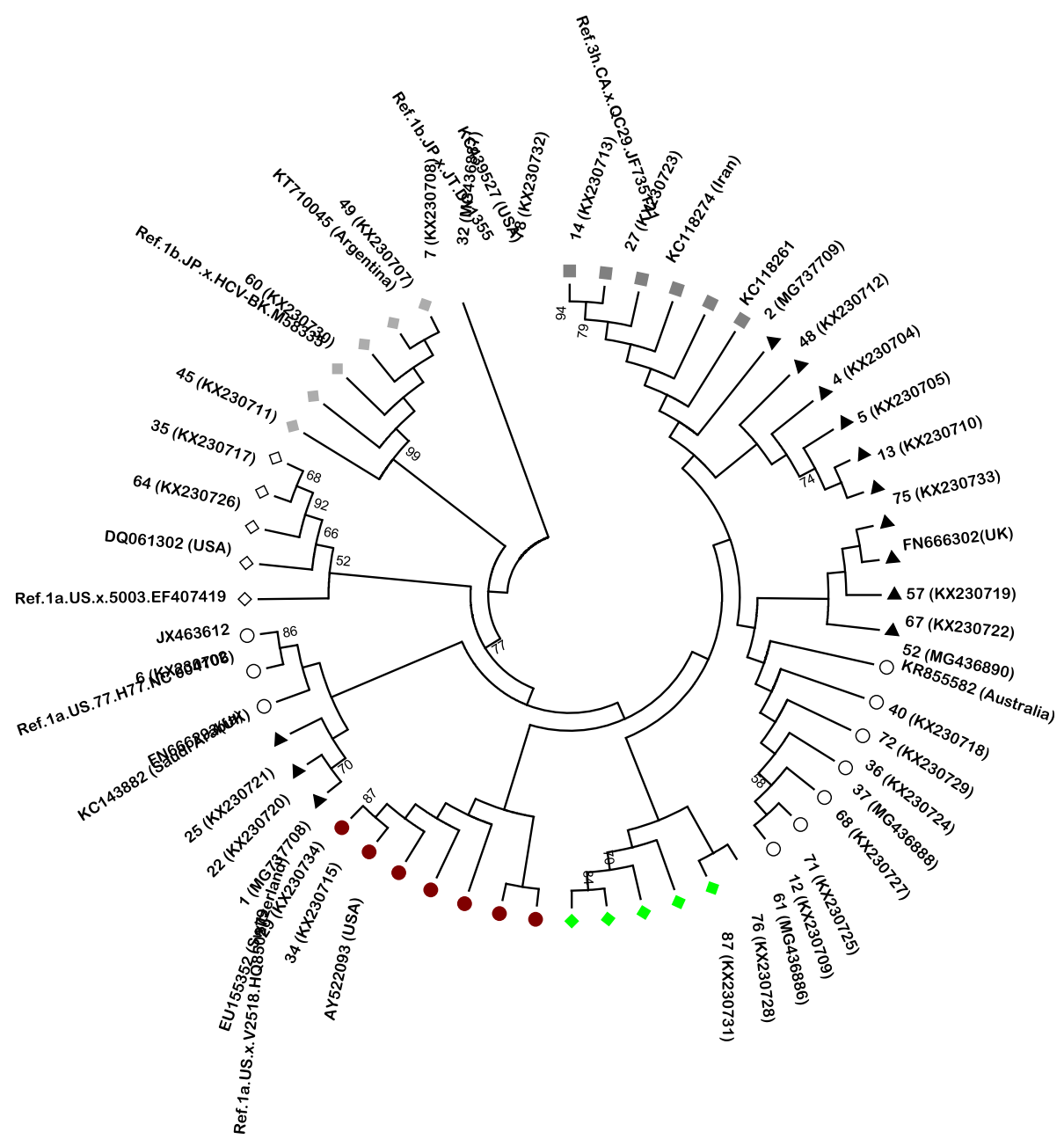

Fig. 1 Phylogenetic analysis of partial core sequences of HCV subtypes 1a, and 1b isolated from patients co-infected with HIV/HCV in Ahvaz, Iran. The sequences found in this study are shown with number. A panel of reference strains retrieved from LOS ALAMOS HCV database identified by their accession number. The origins of reference strains are indicated. Data regarding the geographic origin of HCV reference sequences of Iranian origin are also indicated when available in the GenBank database. Tree were constructed with a neighbor-joining (NJ) method in the MEGA6 software using the Kimura 2-parameter (K2P) model with pairwise-deletion and 1000 bootstrap replicates. Bootstrap values over 50\% are shown 


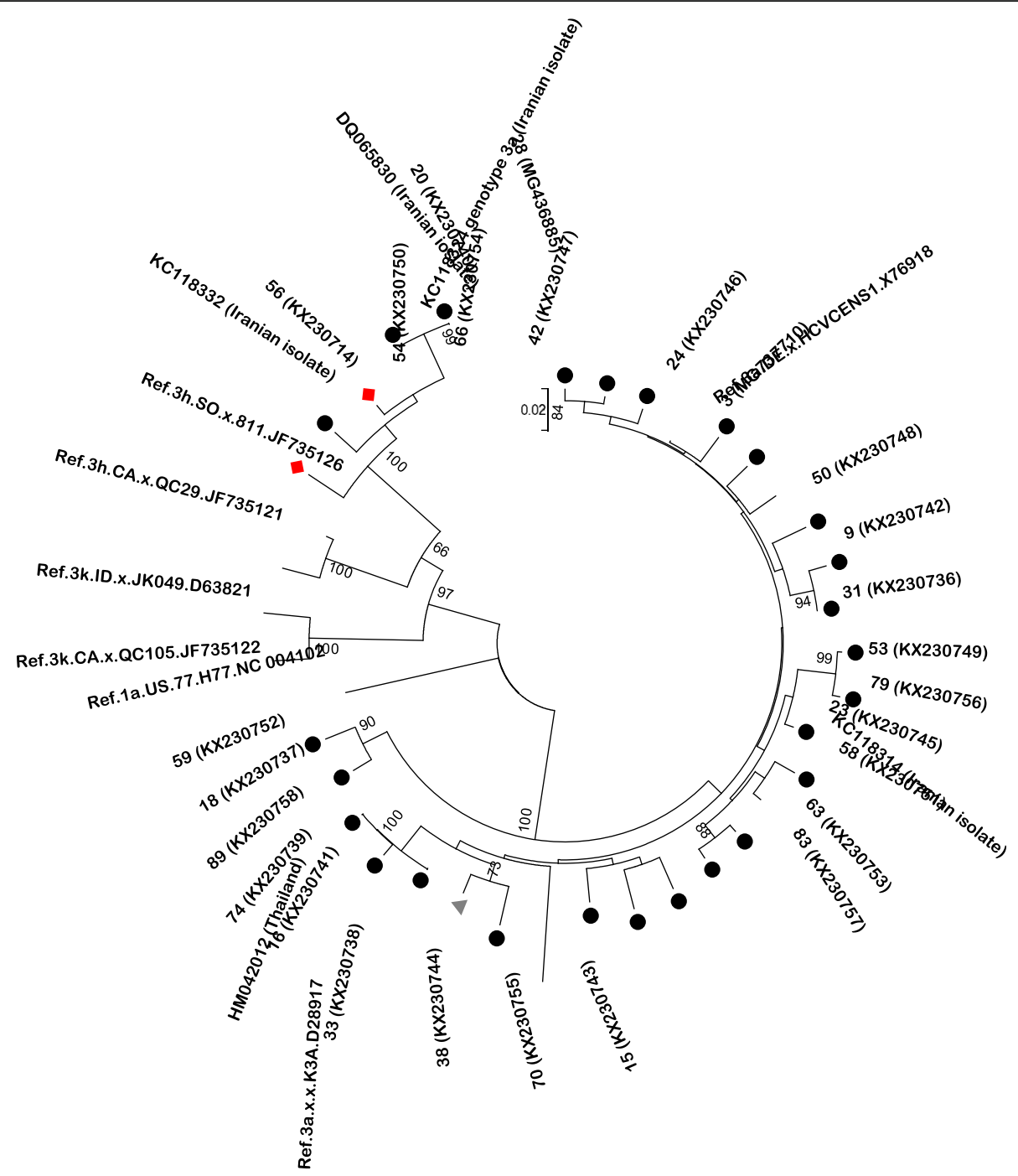

Fig. 2 Phylogenetic analysis of partial core sequences of HCV subtypes 3a, 3b, and $3 \mathrm{~h}$ isolated from patients co-infected with HIV/HCV in Ahvaz, Iran. The sequences found in this study are shown with number. A panel of reference strains retrieved from LOS ALAMOS HCV database identified by their accession number. The origins of reference strains are indicated. Data regarding the geographic origin of HCV reference sequences of Iranian origin are also indicated when available in the GenBank database. Tree were constructed with a neighbor-joining (NJ) method in the MEGA6 software using the Kimura 2-parameter (K2P) model with pairwise-deletion and 1000 bootstrap replicates. Bootstrap values over 50\% are shown

published data, suggesting that $\mathrm{HCV}$ co-infection rates are very high among HIV-infected individuals who use injection drugs [20-22]. In addition, various studies in Iran showed that more than $42.2-85 \%$ of HIV-positive IDUs were co-infected with HCV [23-25].

In other hands, the majority $(97.8 \%)$ of $\mathrm{HIV} / \mathrm{HCV}$ co-infected patients were previously incarcerated, and some of them had re-incarceration records. Incarceration is a significant risk factor for acquisition of HIV and HCV globally. There is strong evidence that incarceration is associated with increased HIV and HCV acquisition risk among injection drug users [22].

Co-infection with HIV accelerates the progression of HCV-related fibrosis and results in a more aggressive course of liver disease [26]. For this reason, treatment of $\mathrm{HCV}$ in this patient population should have a high priority. HCV genotype significantly affects treatment outcome; therefore, genotyping is more predictive for therapy response [27].

Currently, the gold standard for identifying different $\mathrm{HCV}$ genotypes is sequence analysis of specific regions (NS5, core, E1 and 5'UTR) followed by sequence alignment with reference sequences (the consensus sequences in GenBank or the Los Alamos HCV database) and phylogenetic analysis [28, 29]. The present study was performed on 90 individuals who were infected with $\mathrm{HIV}$ and have anti-HCV Abs, indicative of virus exposure, to evaluate the presence of $\mathrm{HCV}$ infection and $\mathrm{HCV}$ 
genotype. We identified five $\mathrm{HCV}$ subtypes in HIV-infected people in Ahvaz, including 1a, 1b, 3a, $3 \mathrm{~h}$, and $4 \mathrm{a}$ (Table 3).

Our results in terms of genetic diversity were inconsistent with some previous studies conducted in this area [30, 31]. The cause of this difference can be due to the two factors; (a) methodology, and (b) study populations. None of these studies used sequencing methods for genotyping and examined haemophilia patients and blood donors.

Despite these differences, we found that subtype 1a (55.2\%) was the most predominant, followed by subtype 3a (35.8\%), which was consistent with other reports in different population groups in this area [31, 32]. It seems that, almost 10 years after the first study in this area, subtypes 1a have remained predominant regardless of the population studied.

The major limitation of this study was the nature of cross-sectional study and small sample size, therefore, participants in this study may not be representative of HIV-1/HCV co-infected individuals from the region. Because of the small sample size, causal relationship between $\mathrm{CD} 4+\mathrm{T}$ cell counts and different HCV subtypes could not be tested. Additionally, most participants received HAART and we could not find the relationship between liver enzyme (ALT, AST) levels and HCV subtypes.

\section{Conclusions}

The present study is the first report on the prevalence and genetic diversity of hepatitis C virus in HIV-infected individuals in southwest Iran. These results suggest that HIV-infected patients are exposed to $\mathrm{HCV}$ at a higher rate than the general population. Intravenous drug use plays an important role in the transmission of this virus. Furthermore, this data shows that there are two major circulating subtypes of $\mathrm{HCV}$ in this area: subtypes 1a and $3 \mathrm{a}$.

\section{Sequence accession numbers}

The Genbank accession numbers for the sequences reported in this paper are KX230704-58, KX258961, and MG73770811 for the partial core region, and MG436880-83 for the partial 5'UTR region.

\section{Abbreviations}

ALT: Alanine aminotransferase; AST: Aspartate aminotransferase; DAA: Directacting antiviral; HAART: Highly active antiretroviral therapy; HCV: Hepatitis C virus; HIV: Human immudeficiency virus; IDU: Injection drug use; PCR: Polymerase chain reaction; VCT: Voluntary counseling and testing

\section{Acknowledgements}

The authors would like to acknowledge all survey participants, staff and employees at VCT sites in Ahvaz city.

\section{Funding}

This work was approved in Infectious and Tropical Diseases Research Center, and was financially supported by Grants (No: 94103) from Research Affairs, Ahvaz Jundishapur University of Medical Sciences, Ahvaz, Iran.

The funding bodies did not play any role in the design of the study and collection, analysis, and interpretation of data, neither in writing the manuscript.

\section{Availability of data and materials}

The datasets generated and analysed during the current study are not publicly available due we don't want share our dataset, but are available from the corresponding author on request.

\section{Authors' contributions}

SG and AT conceived the study, drafted the experimental protocol and manuscript. SK, NK and SS analyzed and interpreted the patients data. SG, AT and SE performed the experiments and analyzed the data. SG and AT and SS contributed to writing, reviewing, and revising the paper. All authors interpreted the data and critically reviewed drafts of the manuscript. All authors edited and approved the final manuscript.

\section{Ethics approval and consent to participate}

The Ethics Committee of the Ahvaz Jundishapur University of Medical Sciences approved the study procedure (Ethical Code:

IR.AGUMS.REC.1394.352). Then, the written informed consent was obtained from all participants before blood sampling. Privacy and confidentiality as well as the anonymity of the participants were ensured at all stages of data collection.

\section{Consent for publication}

Not applicable.

\section{Competing interests}

The authors declare that they have no competing interests.

\section{Publisher's Note}

Springer Nature remains neutral with regard to jurisdictional claims in published maps and institutional affiliations.

\section{Author details}

${ }^{1}$ Infectious and Tropical Disease Research Center, Health Research Institute, Ahvaz Jundishapur University of Medical Sciences, Ahvaz, Iran. ${ }^{2}$ Department of Virology, School of Medicine, Hamadan University of Medical Sciences, Hamadan, Iran. ${ }^{3}$ Department of Health Services Management, School of Health, Ahvaz Jundishapur University of Medical Sciences, Ahvaz, Iran.

${ }^{4}$ Infectious Diseases Research Center, Birjand University of Medical Sciences, Birjand, Iran.

Received: 25 February 2019 Accepted: 30 April 2019

Published online: 08 May 2019

References

1. Platt L, Easterbrook P, Gower E, McDonald B, Sabin K, McGowan C, et al. Prevalence and burden of HCV co-infection in people living with HIV: a global systematic review and meta-analysis. Lancet Infect Dis. 2016;16(7): 797-808.

2. Price JC, Thio CL. Liver disease in the HIV-infected individual. Clinical gastroenterology and hepatology : the official clinical practice journal of the American Gastroenterological Association 2010:8(12):1002-12.

3. Boucle S, Bassit L, Ehteshami M, Schinazi RF. Toward elimination of hepatitis $B$ virus using novel drugs, approaches, and combined modalities. Clinics in Liver Disease. 2016;20(4):737.

4. Naggie S, Sulkowski MS. Management of Patients Coinfected with HCV and HIV: a close look at the role for direct-acting antivirals. Gastroenterology. 2012;142(6):1324-34 e3.

5. Simmonds $P$. The origin of hepatitis $C$ virus. Curr Top Microbiol Immunol. 2013;369:1-15.

6. Smith DB, Bukh J, Kuiken C, Muerhoff AS, Rice CM, Stapleton JT, et al. Expanded classification of hepatitis $C$ virus into 7 genotypes and 67 subtypes: updated criteria and genotype assignment web resource. Hepatology (Baltimore, Md). 2014;59(1):318-27. 
7. Borgia SM, Hedskog C, Parhy B, Hyland RH, Stamm LM, Brainard DM, et al. Identification of a novel hepatitis C virus genotype from Punjab, India: expanding classification of hepatitis C virus into 8 genotypes. J Infect Dis. 2018:218(11):1722-9.

8. Messina JP, Humphreys I, Flaxman A, Brown A, Cooke GS, Pybus OG, et al. Global distribution and prevalence of hepatitis $C$ virus genotypes. Hepatology (Baltimore, Md). 2015;61(1):77-87.

9. Cloherty G, Talal A, Coller K, Steinhart C, Hackett J, Dawson G, et al. Role of serologic and molecular diagnostic assays in identification and Management of Hepatitis C Virus Infection. J Clin Microbiol. 2016:54(2):265-73.

10. Mahmud S, Akbarzadeh V, Abu-Raddad LJ. The epidemiology of hepatitis C virus in Iran: systematic review and meta-analyses. Sci Rep. 2018;8(1):150

11. Alavian SM, Asl MA, Lankarani KB, Shahbabaie MA, Bahrami Ahmadi A, Kabir A. Hepatitis $C$ infection in the general population of Iran: a systematic review. Hepat Mon. 2009;9(3):211-23.

12. Ghaderi-Zefrehi H, Gholami-Fesharaki M, Sharafi H, Sadeghi F, Alavian SM. The distribution of hepatitis C virus genotypes in middle eastern countries: a systematic review and meta-analysis. Hepat Mon. 2016;16(9):e40357.

13. Khodabandehloo M, Roshani D. Prevalence of hepatitis C virus genotypes in Iranian patients: a systematic review and meta-analysis. Hepat Mon. 2014;14(12).

14. Sadeghi F, Salehi-Vaziri M, Almasi-Hashiani A, Gholami-Fesharaki M, Pakzad $\mathrm{R}$, Alavian SM. Prevalence of hepatitis C virus genotypes among patients in countries of the eastern Mediterranean regional office of WHO (EMRO): a systematic review and meta-analysis. Hepat Mon. 2016;16(4):e35558.

15. Ghafari S, Memarnejadian A, Samarbaf-zadeh A, Mostafavi E, Makvandi M, Salmanzadeh S, et al. Prevalence of HIV-1 transmitted drug resistance in recently infected, treatment-naïve persons in the southwest of Iran, 20142015. Arch Virol. 2017;162(9):2737-45.

16. Ohno O, Mizokami M, Wu RR, Saleh MG, Ohba K, Orito E, et al. New hepatitis $C$ virus $(\mathrm{HCV}$ ) genotyping system that allows for identification of HCV genotypes 1a, 1b, 2a, 2b, 3a, 3b, 4, 5a, and 6a. J Clin Microbiol. 1997; 35(1):201-7.

17. Murakami S, Takahashi Y, Yoshida S, Fuke I, Ohmae K, Mori C, et al. Highly sensitive detection of viral RNA genomes in blood specimens by an optimized reverse transcription-polymerase chain reaction. J Med Virol. 1994:43(2):175-81.

18. Tamura K, Stecher G, Peterson D, Filipski A, Kumar S. MEGA6: molecular evolutionary genetics analysis version 6.0. Mol Biol Evol. 2013;30(12):2725-9.

19. Kimura M. A simple method for estimating evolutionary rates of base substitutions through comparative studies of nucleotide sequences. J Mol Evol. 1980;16(2):111-20.

20. Alter MJ. Epidemiology of viral hepatitis and HIV co-infection. J Hepatol. 2006:44(1 Suppl):S6-9.

21. Taylor LE, Swan T, Mayer KH. HIV coinfection with hepatitis C virus: evolving epidemiology and treatment paradigms. Clin Infect Dis. 2012;55 Suppl 1(Suppl 1):S33-42.

22. Stone J, Fraser H, Lim AG, Walker JG, Ward Z, MacGregor L, et al. Incarceration history and risk of HIV and hepatitis $C$ virus acquisition among people who inject drugs: a systematic review and meta-analysis. Lancet Infect Dis. 2018;18(12):1397-409.

23. Dehghani-Dehej F, Sarvari J, Esghaei M, Hosseini SY, Garshasbi S, Kalantari S, et al. Presence of different hepatitis $C$ virus genotypes in plasma and peripheral blood mononuclear cell samples of Iranian patients with HIV infection. 2018;90(8):1343-1351.

24. Alipour A, Rezaianzadeh A, Hasanzadeh J, Rajaeefard A, Davarpanah MA, Hasanabadi M. High prevalence of HCV coinfection in HIV-infected individuals in shiraz, Islamic Republic of Iran. Eastern Mediterranean health journal $=$ La revue de sante de la Mediterranee orientale $=$ alMajallah al-sihhiyah li-sharq al-mutawassit 2013;19(12):975-981.

25. Afzali H, Momen-Heravi M, Farokhzad A. Epidemiological distribution and genotype characterization of the hepatitis C virus among HIV patients in Kashan. Iran Hepat Mon. 2016;16(7):e30459.

26. Kirk GD, Mehta SH, Astemborski J, Galai N, Washington J, Higgins Y, et al. HIV, age, and the severity of hepatitis $C$ virus-related liver disease: a cohort study. Ann Intern Med. 2013;158(9):658-66.

27. Nouroz F, Shaheen S, Mujtaba G, Noreen S. An overview on hepatitis C virus genotypes and its control. Egyptian Journal of Medical Human Genetics. 2015;16(4):291-8.

28. Tian D, Li L, Liu Y, Li H, Xu X, Li J. Different HCV genotype distributions of HIV-infected individuals in Henan and Guangxi, China. PLoS One. 2012;7(11): e50343.
29. Ohno T, Lau JY. The "gold-standard," accuracy, and the current concepts: hepatitis C virus genotype and viremia. Hepatology (Baltimore, Md) 1996; 24(5):1312-1315.

30. Assarehzadegan MA, Boroujerdnia MG, Zandian K. Prevalence of hepatitis B and $\mathrm{C}$ infections and HCV genotypes among Haemophilia patients in Ahvaz, Southwest Iran. Iran Red Crescent Med J. 14(8):470-4.

31. Farshadpour F, Makvandi M, Samarbafzadeh AR, Jalalifar MA. Determination of hepatitis C virus genotypes among blood donors in Ahvaz, Iran. Indian J Med Microbiol. 2010;28(1):54-6.

32. Hajiani E, Hashemi SJ, Masjedizadeh A, Shayesteh AA, Jalali F. Genotypic analysis of hepatitis $C$ virus in Khuzestan province, southwestern Iran. Middle East journal of digestive diseases. 2011;3(2):126-30.
Ready to submit your research? Choose BMC and benefit from:

- fast, convenient online submission

- thorough peer review by experienced researchers in your field

- rapid publication on acceptance

- support for research data, including large and complex data types

- gold Open Access which fosters wider collaboration and increased citations

- maximum visibility for your research: over $100 \mathrm{M}$ website views per year

At BMC, research is always in progress.

Learn more biomedcentral.com/submissions 